Article

\title{
Creative Environments: The Geo-Poetics of Allen Ginsberg
}

\author{
Alexandre Ferrere \\ English Department, Paris Nanterre University, 92000 Nanterre, France; ferrere.alexandre@hotmail.fr
}

Received: 3 May 2020; Accepted: 27 August 2020; Published: 1 September 2020

\begin{abstract}
As was the case for other writers from the Beat Generation, geography is more than simply a setting for Allen Ginsberg's work, as his poetry also bears the imprint of the influence of the landscapes through which he traveled in his mind and poetic practice. In the 1950s, the same decade which saw the composition of Ginsberg's Howl, Guy Debord and his followers developed the concept of "psychogeography" and "dérive" to analyze the influence of landscapes on one's mind. The Debordian concept of psychogeography implies then that an objective world can have unknown and subjective consequences. Inspired by Debord's theories and through the analysis of key poems, this paper argues that a psychogeographical focus can shed new light on ecocritical studies of Ginsberg's poetry. It can indeed unveil the complex construction of the poet's own space-time poetics, from hauntological aspects to his specific composition process.
\end{abstract}

Keywords: Allen Ginsberg; Beat Generation; poetry; poetics; memory; Guy Debord; psychogeography; landscape; ecocriticism

\section{Introduction}

In his introduction to Geocriticism: Real and Fictional Spaces, Bertrand Westphal writes: "The perception of space and the representation of space do not involve the same thing" (Westphal 2011, p. 1). Passing from an objective notion of "space" to a subjective concept of "place" is to take a step towards psychogeography, as it involves both the perception and the representation of one's surroundings. In order to understand and to study the influence of geography on emotion, Guy Debord and the Situationist International developed the concept of psychogeography as well as an experimental method they named the "dérive" - to wander in a landscape so as to re-discover it. Besides reinforcing the position of the individual in the world, psychogeography is, in the Debordian system, a way for citizens to reclaim their territories. But the Debordian system also advocates for a complete revolution of urbanism and architecture in creating new zones according to psychogeographical reports-as written in Potlatch \#5: "Poetry is written in the shape of cities. We will thus build some overwhelming ones" (Conord 1954c. My translation).

In the wider theoretical "environment" of ecocriticism, psychogeography can be a useful tool to analyze literature, especially if we consider written texts as creative psychogeographical accounts. From this perspective, Allen Ginsberg's work is particularly striking, as the number of poems involving his experience of different places can reveal (as well as his journals, sometimes written in very specific places, like his Indian Journals or his South American Journals). Indeed, his Odyssean adventures in more than sixty countries around the globe have inevitably shaped his poetry, not only in terms of redefinitions of space but also in his vision of society as well as in his very methods of composition. And while in political terms psychogeography could be seen as a defense of freedom of movement, it could be considered poetically as an emotional interpretation of the world. The self is at the center of psychogeography, as it can only be experienced by a subject, it is therefore not surprising that Ginsberg, often labeled a "confessional" poet, wrote many poems about his relationship to his close environment. 
The deep involvement of the Beats in environmental (re)actions is well-known; Michael McClure even considered the "poetry of the Beats" as "the first literary wing of the environmental movement" (Meltzer 2001, p. 185). Nevertheless, a part of Ginsberg's poetry is not only about having to cope with an environmental crisis. Sometimes, it is also the poet's own crisis, lamentations, or visions that are explored in the larger frame of an environmental and urban downfall. In other words, it seems that ever-changing landscapes are not always observed for their essence nor for the impact mankind can have on them; it is also a way to express what these landscapes can symbolize in the poet's life and how they can represent the inner tensions between Ginsberg and the outside world in a social and political way.

Historically, analyzing Ginsberg's poetry through the lens of Debord's theories could appear as a counterintuitive experiment. Indeed, Debord and the Situationists were rather hostile to Beat writers-they are described as "mystical cretins" in the first issue of Internationale Situationniste (Debord 1958a). Furthermore, Greil Marcus remarks that Alexander Trocchi, who was very close to Debord, was even indirectly excluded from the Situationists because of his relationship with Allen Ginsberg (Marcus 2011, p. 359). Nonetheless, both Ginsberg and Debord's followers were advocating for a new vision of landscapes through direct and subjective experiences of them, in a larger counter-cultural and intellectual renewal. Their works were also often linked to political criticisms of capitalism and urbanism. While the Beats were writing "both a critique of urban-industrial civilization and a search to recover authentic human identity" (Stephenson 2009, p. 177), Debord wrote, "urbanism [ ... ] is capitalism's method for taking over the natural and human environment" (Debord 2005, p. 95). Their ideological points of contention are in that sense not antinomic when it comes to environment, ecology, and urbanism. Rooted in Debordian theories, this study, therefore, considers psychogeography as a critical tool that can bring a new understanding to how the objectivity of the world has been subjectively and poetically transcribed by the poet. In this paper, we will explore Allen Ginsberg's subtle and heterogeneous constructions of his own development of space-time poetics. From hauntological aspects to eco-linguistical approaches and genetic criticism of the poet's methods of composition, Allen Ginsberg's creative process will be analyzed with regard to what Guy Debord called "psychogeographical variations", as applied to the "field" of poetry.

\section{Psychogeography or the Art of Awareness}

Almost every issue of the magazine Potlatch (1954-1957), the "information bulletin of the French group of the Lettrist International" ${ }^{\prime 1}$ in which Guy Debord actively participated, is infused with the notion of psychogeography - a concept directly inherited from Ivan Chtcheglov (also known as Gilles Ivain) ${ }^{2}$ and his essay Formulaire pour un urbanisme nouveau. The word psychogeography is first introduced along with the notion of a game in the article Psychogeographical Game of the Week, in Potlatch \#1:

Depending on what you are after, choose an area, a more or less populous city, a more or less lively street. Build a house. Furnish it. Make the most of its decoration and surroundings. Choose the season and the time. Gather together the right people, the best records and drinks. Lighting and conversation must of course be appropriate, along with the weather and your memories.

If your calculations are correct, you should find the outcome satisfying. (Please inform the editors of the results.) (Conord 1954a)

1 It will be later subtitled the "information bulletin of the Lettrist International" until finally the Lettrist International becomes the Situationist International.

2 Gilles Ivain will be excluded from the Internationale Lettrist in 1954, as mentioned in Potlatch \#2. 
In this unattributed article, the term "psychogeography" is not defined, but the juxtaposition of words like "area", "city", "memories", and "outcome" suggests that "psychogeography" focuses on what happens at the frontier of two worlds, the physical and the emotional. In the second issue of Potlatch, Guy Debord (who signed Guy-Ernest Debord) published an article entitled Exercise in Psychogeography, which emphasizes the interactive features of the still undefined term "psychogeography":

The postman Cheval is psychogeographical in architecture

Arthur Cravan is psychogeographical in hurried drifting.

Jacques Vaché is psychogeographical in dress.

Louis II of Bavaria is psychogeographical in royalty.

Jack the Ripper is probably psychogeographical in love. (Conord 1954b)

Psychogeography is then, in its first two mentions in Potlatch, either a game to create a new "situation" — based on the "dialectic setting-behavior" (Debord 1957)—or a poetic exercise unveiling the confrontation of a subject and their environment (whether it be a natural environment or an intimate environment). But those are not satisfying in terms of intellectual definition and implication; is psychogeography a concept? A tool? A process? Subsequent issues of Potlatch bring no solid answer to those questions, even though the term is used several times. But psychogeography is part of a wider philosophy in which urbanism plays a key role. The aim of this avant-garde group of thinkers, who sought to meld arts and politics, is to "create situations" (Conord 1954d), to offer the unexpected, partly through what they called "influential urbanism" (Conord 1954d). It is important to underline that, even though urbanism could be thought of as in opposition to ecological questions, this is not the case for Debord's vision of it. Indeed, besides advocating against the "temporal fixation of cities" (and "fixation of people at certain points of a city"), the museumification of cities, and purely aesthetical architecture, Debord asks for "moving cities", "the overgrowth of tropical vegetation", and a "marriage with nature more audacious than anything attempted by Frank Lloyd Wright" (Debord 1959).

Despite the fact that psychogeographical reports (as well as maps) were published in Potlatch by members of the Lettrist group, in which they described as precisely as possible the influence of the environment on their feelings (and in that sense being what could be called ecocritical reports), Debord would define "psychogeography" only in 1955. Indeed, in an article entitled Introduction to a Critique of Urban Geography, published in the Belgian magazine Les Lèvres Nues ${ }^{3}$, Debord wrote:

Psychogeography could set for itself the study of the precise laws and specific effects of the geographical environment, consciously organized or not, on the emotions and behavior of individuals. The adjective psychogeographical, retaining a rather pleasing vagueness, can thus be applied to the findings arrived at by this type of investigation, to their influence on human feelings, and even more generally to any situation or conduct that seems to reflect the same spirit of discovery. (Debord 1955)

One interesting aspect of psychogeography as defined by Debord is, therefore, its protean nature, whether it be in its use or its object. Nevertheless, the "pleasing vagueness" of the word does not mean imprecise analysis, as at the heart of the word lays the idea that geography, landscapes, and environments actively trigger emotion and physical reactions. In a sense, Debord and the Situationists sought to analyze the mechanisms at the frontier between an open world and a secret mind-what is seen and what is felt. Thanks to this "vagueness" - and thus, to the capacity of psychogeography to be adapted to new situations and contexts-the Debordian definition of psychogeography helps to unveil certain characteristics of Allen Ginsberg's poetry, especially when used in an ecocritical perspective.

Intrinsically linked to the notion "psychogeography" and equally important for Debord's followers, the concept of "dérive" is also a key element when it comes to psychogeographical analysis. 
The "dérive", which Nathalie Caritoux defines as the "experimental method" of psychogeography ((Caritoux and Villard 2017, p. 8) My translation), is first described in the first issue of Internationale Situationniste as:

A mode of experimental behavior linked to the conditions of urban society: a technique of rapid passage through varied ambiances. The term also designates a specific uninterrupted period of dériving. (Debord 1958a)

In other words, the "dérive" 4 is an exploratory process—cabs are in this regard the preferred vehicle (Dahou 1954a) - used by psychogeographers in order to produce reports and maps, as architecture is seen by the Situationists as "a means of knowledge and a means of action" (Debord 1958a). In Potlatch \#14, the "dérive" is also defined as a "method of aimless displacement" founded on the "influence of scenery" (Dahou 1954b. My translation). This point will be important when we will study some poems written during Allen Ginsberg's own wanderings.

But a few years after offering the first definition of "psychogeography", Debord wrote in the first issue of Internationale Situationniste, in 1958:

A situation is also an integrated ensemble of behavior in time. It is composed of actions contained in a transitory decor. These actions are the product of the decor and of themselves, and they in their turn produce other decors and other actions. How can these forces be oriented? (Debord 1958a)

In this passage, besides advocating for an active reshaping of urbanism, Debord adds a new feature to psychogeography that will be important when studying Allen Ginsberg's poetry. Psychogeographical reactions seem indeed to be circular and could be seen as active reciprocity between the landscape and observer. More than a mere mirroring effect, the landscape affects the observer who, in turn, affects the image and representation of the landscape following a phenomenological impulse. We will see later how this sensitive exchange triggered Ginsberg's compositions, but also what forms this circularity takes on in his poetry.

\section{Towards a Geography of Memories}

In Geocriticism: Real and Fictional Spaces, Bertrand Westphal wrote that "The concrete details of geography often relate to a spiritual hermeneutic rather than to immediate observation" (Westphal 2011, p. 2). Adapted to an ecocritical stance, what is implied here is strongly psychogeographical, even phenomeno-geographical, to the extent that landscapes convey meaning for the psychogeographer, the writer, or simply the conscious individual-in most cases, an internal representation almost always associated with feelings. In that sense, psychogeography can be generally considered, as implied above, a re-evaluation of urbanism, an invitation to build anew everyday scenery according to inner perceptions. This metaphysical sense of belonging to a territory that exists more through how it is emotionally perceived than objectively observed is rooted in ecocriticism and central to Ginsberg's poetry. His tribute poem entitled At Apollinaire's Grave, recalling the poet's visit to the grave of the famous French poet, reflects this experience of emotionally heightened response to the poet's immediate surroundings:

the universe is a graveyard and I walk around alone in here

knowing that Apollinaire was on the same street 50 years ago

his madness is only around the corner and Genet is with us stealing books (Ginsberg 2006, p. 188)

Ginsberg emphasizes here what is called the spirit of places: when a place is so loaded with a strong sense of history that it can transcend temporal structures. Time and space appear here as two sides

4 The term is already used in Gilles Ivain's essay mentioned earlier. 
of the same coin - the poem is somewhat balancing on its edge. The place becomes a personal book of history. The place is, as Nathalie Caritoux wrote, not "an empty frame to fill with behaviors" but "the cause, the source of behaviors" ((Caritoux and Villard 2017, p. 10) My translation). Therefore, this phenomenal impulse (in the phenomenological sense) of a past inhabiting a place could be seen as an extension of Walter Benjamin's idea of unconscious memories, to the extent that unintentional memories emerge from the junction of collective and personal memories (Benjamin 2000, p. 335). And it is also the persistence of place through memories that is at work in this poem, as symbolized in this passage where hands are part of the forces pushing the poet into the geography of the mind (Ginsberg 2006, p. 188):

\section{Already our hands have vanished from that place my hand writes now in a Room in Paris Git-le-Coeur}

Between those lines, the reader understands that a place, when infused with poetics, can complicate the notion of time- not as in the cliché of overcoming death in writing ${ }^{5}$, but in transcending time through space (reversing thus the equation of space transcended by time). At the heart of this poem is not so much the temporal difference between two eras (a dividing force that is physically experienced), but the common ground that allows the melding of those eras into one another (the merging force geography gives birth to). Therefore, in the second part of the poem, Ginsberg describes himself at the Bateau Lavoir, in the company of artists like Jacob, Picasso, Tzara, Breton, Cendrars, Gide, etc. The reader easily understands that the conventional notion of time is abolished by the very fact that the poet wanders ("dérive") in the same place as these French artists did once. Another important element in this poem (as in other works involving "meeting" other deceased artists, like Whitman or Lorca in A Supermarket in California) is that Ginsberg uses his imagination to physically describe himself amongst those artists he admired. Once again, time is overcome through the place and those souvenirs are ones of situations that never happened.

Allen Ginsberg ends his three-part poem with a line that summarizes this syncretism of perspectives: "I am buried here and sit by my grave beneath a tree" (Ginsberg 2006, p. 190). This line does not only cloud spatial and temporal structures, but it also connects the collective and Ginsberg's own memories. This work balances between a tribute and a personal reflection, and the place is the first impulse of this movement. This poem, by essence, unveils the geographical tensions at work within the poet's mind: the poet shuttles between two different eras made from the same material, and what they have in common is the scenery. To use Debordian vocabulary, the result of the confrontation between the poet and his very surrounding is a psychogeographical poem in itself-and Ginsberg's reflexive "dérive" through the graves gives birth to a new, specific and actualizing "situation", as was the aim of the Situationists.

But the landscape in Allen Ginsberg's poetry is not lived through the senses only: imagination is here an essential but paradoxical condition ${ }^{6}$. In fact, Jean-Jacques Wunenburger distinguishes imagination, which he describes as "too close to fiction", from the imaginal which is made of "a group of images, loaded with affective values (positive or negative) [ ... ] which are the subject of a

5 On this topic, and in this poem, Ginsberg was rather clear, and he wrote lines like "my temporary hands" and "my temporary American Howl" (Ginsberg 2006, p. 188).

6 In Over Kansas, Ginsberg writes about the limit of imagination:

And down there's Hollywood,

The starry world below [...].

Not even the human

Imagination satisfies

The endless emptiness of the soul

(Ginsberg 2006, p. 124). 
shared experience, of a vision of the world shared by the participants of a joint space" ((Caritoux and Villard 2017, p. 220) My translation). In this poem, Ginsberg composes then from both imagination and imaginal. Nathalie Caritoux adds to this notion of imaginal the idea of kairros, which could be defined as the right moment from which a revelation can occur (Caritoux and Villard 2017, p. 21). These two elements, the imaginal of the place, which is large, and the kaïros, the moment of the visit, which is intimate, form the invisible frame of the poem. In Ginsberg's poem, the place has a subjective meaning rooted in an objective ground. But the place is as much a projection, through the emotional phenomenology of the poet (Caritoux and Villard 2017, pp. 220-21), as a projector actualizing the position of the poet's mind in a specific environment, which will lead to the poetic gesture. Here, the whole poem, because of its raw material, could be considered a projection, while traces of the place acting as a projector on the poet are scattered throughout the poem-a line summarizes it: "Peter Orlovsky and I walked softly thru Père Lachaise we both knew we/would die" (Ginsberg 2006, p. 188). The place is an active muse that transforms the poet and his knowledge of his own identity and temporality; and the place, in return, is transformed by the poet in an effort of imagination. This dynamic exchange, therefore, changes the nature of the relation between the poet and the place.

This psychogeographical porosity is at work in many of Ginsberg's poems; one of the most striking examples is his famous Kaddish, written after the death of his mother. Many passages in the poem highlight the importance of places, which are always a poetic trigger for memories. For example, right from the beginning, the poet is taken by the city that seems to be the only solid ground on which Ginsberg could stay in his mourning, his thoughts being spread in place and time (Ginsberg 2006, p. 217):

Strange now to think of you, gone without corsets \& eyes, while I walk on the sunny pavement of Greenwich Village.

downtown Manhattan, clear winter noon, and I've been up all night, talking, talking, reading the Kaddish aloud, listening to Ray Charles blues shout blind on the phonograph

As in At Apollinaire's Grave, the "dérive" of the poet motivates his later recollections. The genealogy of the poem is thus blown away in the landscape-born from a "situation" that is intrinsically lost because experienced. A few lines below, Ginsberg writes:

It leaps about me, as I go out and walk the street, look back over my shoulder, Seventh Avenue, the battlements of window office buildings shoulddering each other high, under a cloud, tall as the sky an instant-and the sky above-an old blue place.

or down the Avenue to the south, to-as I walk toward the Lower East Side

-where you walked 50 years ago, little girl—from Russia, eating the

first poisonous tomatoes of America-frightened on the dock-

then struggling in the crowds of Orchard Street toward what?- -toward

Newark-(Ginsberg 2006, p. 217).

Again, the poet walks and remembers his mother who died earlier, and like in At Apollinaire's Grave, the place impacts the poet and the poet impacts the place. The main difference though is that the poet is transported by a historical force, which is here not collective as in At Apollinaire's Grave but personal. In the entire reflection that is Kaddish the notion of place is confused, disturbed by actual memories, imaginative ghosts, and projections of the mind. The landscape blurs the notion of time and acts like a mirror reflecting the past for Ginsberg. The city becomes an intimate wound and this poem a report of eco-trauma, the simple fact of moving triggering metaphysical questions, each detail of the city forming a scar, like in this passage: 
[... ] Strange to have moved

thru Paterson, and the West, and Europe and here again,

with the cries of Spaniards now in the doorstoops doors and dark boys on the

street, fire escapes old as you

-Tho you're not old now, that's left here with me-(Ginsberg 2006, p. 218)

Time and place are blended into each other, the poet making one with the universe ("Myself, anyhow, maybe as old as the universe"). The poet is here a psychogeographer of personal trauma, exploring his own memories in space throughout the poem.

\section{Natural Echoes: Eco-Linguistical Readings}

The very moving final part of the poem is also interesting to analyze in terms of ecocriticism-the last lines read:

caw caw all years my birth a dream caw caw New York the bus the broken shoe the vast highschool caw caw all Visions of the Lord Lord Lord Lord caw caw caw Lord Lord Lord caw caw caw Lord (Ginsberg 2006, p. 235)

This passage is almost an animistic ritual, merging religious ("Lord") with natural power ("caw"), echoing each other. Therefore, nature harmoniously embodies the mourning of the poet in a natural, elegiac form. This could be linked to a claim formulated by Mircea Eliade: "All over the world learning the language of animals, especially of birds, is equivalent to knowing the secret of nature" (Manes 1996, p. 19). In that sense, natural elements accompany the poet's sentiments throughout the absurdity of death: a secret pact, known only to the landscapes and the poet is formed. The intimacy of death is made part of the poet's surroundings and goes beyond the language spoken by mortals. Confronting death becomes, then, a metaphysical secret that can only be revealed in the mourning process, when the poet is made lonesome, his "naked" soul contemplating his surroundings. Death is reevaluated, debunked, and re-mystified through space and nature. The power of nature is invoked, and the crow is more than a mere symbol here-it is a vision of nature as an understanding entity. Christopher Manes' take on animism and language (from which I draw Eliade's quotation) is also insightful:

[ ... ] the "animistic subject" [is] a shifting, autonomous, articulate identity that cuts across the human/nonhuman distinction. Here, human speech is not understood as some unique faculty, but as a subset of the speaking of the world. (Manes 1996, p. 19)

This last part of Kaddish is a cry for meaning before the unreal feature of death and a desperate realization that it is all part of a natural cycle. The whole poem is not only about what is located within the Anthropocene but also it is a way to zoom out, to shift focus from the individual towards the gist of the universe, and to a wider sense of belonging. In other words, Allen Ginsberg's poetics could be seen as a counterpart of the Camusian idea of the absurdity of mankind before the universe. On the contrary, Ginsberg's poetic is one of union, transcendence, and humility-as Nathalie Caritoux wrote "The distinction between the subject and the world becomes ineffective" ((Caritoux and Villard 2017, p. 71) My translation).

But a short eco-linguistical survey of one term used in different Ginsberg's poems can also underline the extent to which Ginsberg's poetry is tentatively overcoming space through language and against time. One of the most interesting examples is his use of the word "Mannahatta" which appears mostly in his collection The Fall of America (which will be at the heart of the last part of this essay). The Ginsbergian use of the word "Mannahatta" reflects the influence of Walt Whitman on the Beat poet, "Mannahatta" being the name of one of Whitman's poems. This word refers to the "aboriginal" (Ginsberg 2006, p. 790) name of New York City, a term used by the Lenape. Ginsberg uses this word as an invocation (often near the mention of Whitman) like in "Bayonne Entering NYC" (Ginsberg 2006, p. 428): 
Whizz of bus-trucks shimmer in Ear over red brick under Whitmanic Yawp Harbor here roll into Man city, my city, Mannahatta Lower East Side ghosted \& grimed with Heroin, shit-black from Edison towers on East Rivers rib-

Ginsberg develops here an interesting linguistical conception of the name "Manhattan", going from "Man city" to "my city", emphasizing a sense of both objective and subjective belonging to the city. But the mention of Mannahatta also invokes historical forces, in an almost Rousseauist vision of a nature that has been lost and destroyed by modernity. This point recalls the beginning of Ginsberg's poem entitled "Ecologue" (a wordplay on "eclogue"), a Rousseauist vision of an apocalyptic America:

In a thousand years, if there's History

America'll be remembered as a nasty little Country

Full of Pricks, thorny hothouse rose

Cultivated by the Yellow Gardeners.

[...]

Earth rolling round, epics on archaic tongues

Fishermen telling island tales-

All autos rusted away,

Trees everywhere. (Ginsberg 2006, p. 550)

Later, in the same poem, Ginsberg also writes, "All landscapes have become Phantom" (Ginsberg 2006, p. 463). This dystopian or Rousseauist cartography of a future America-depending on the reader's point of view-echoes Deleuze and Guattari's claim that "writing has nothing to do with signifying. It has to do with surveying, mapping, even realms that are yet to come" (Deleuze and Guattari 1987, pp. 4-5). But in the passage of Bayonne Entering NYC mentioned above, the city is also associated with human features, like the "East River's rib" - this goes with the deep sense of belonging to a city that is growing, and here somewhat on the verge of dying. The term "Mannahatta", which also appears on the back cover of The Fall of America is also present in the long poem Iron Horse-again associated with organic terms (Ginsberg 2006, p. 464):

Mind wanders. Sleep, cough \& sweat...

Mannahattas

tunnel-door cobbled for traffic,

trucks into that mouth

Ginsberg also writes in the same poem: "crowd iron cancer on the city's throat" (Ginsberg 2006, p. 457) recalling Mathieu Perrot's analysis of "the poetic of the poisoned city" which is here insightful: "just like cancer changes living matter into dead matter, industrial societies' inclination to inorganic matters is the very proof of their degeneration" (Perrot 2018, p. 43). In his pamphlet A Sick Planet Debord would argue that "it is not the symptoms but the illness itself that must be cured" (Debord 2008, p. 91). Therefore, Ginsberg's use of an aboriginal name for Mannahatta would be an act of resistance against this metaphorical degeneration. Occurrences of "Mannahatta" can be found in other poems like Memory Gardens, Friday the Thirteenth or Contest of Bards. Of course, this use of the word "Mannahatta" is part of a wider Ginsbergian vision inherited from Whitman, of a primary land, "an appreciation of the Amer-Indian vision of America as "Turtle Island", as he said in an interview (Geneson and Ginsberg 1975, p. 30). 
This vision of an original lost land, of which traces can be perceived through the spirit of places, is also linked to-and contrasted by - a Ginsbergian and apocalyptical vision of the city, most famously represented in Howl. An eco-Marxist reading of Ginsberg's poems (as well as of other Beat works, such as Kerouac's On the Road, Diane di Prima's Revolutionary Letters, etc.), would stress the need to reclaim (or to save) the landscape from capitalistic views. This is what the Situationists were fighting against with their own idea of urbanism. They, for example, criticized Haussmann for modeling streets according to the size of cannons, Le Corbusier for wanting to "suppress the streets", ending thus their "chances of insurrections and meetings", and modern urbanism for following Police directives (Conord 1954c). Mainstream urbanism becomes a tool of police or capitalistic oppression against the citizen, as Ginsberg observes in the opening lines of the second part of Howl:

What sphinx of cement and aluminum bashed open their skulls and ate up their brains and imagination?

In Greek mythology, the sphinx is a cruel and heartless creature killing and eating those who are not able to answer its riddles, famously represented in the myth of Oedipus. The city is seen then as an unsolvable riddle, brutally crushing its crazed youth. And Ginsberg goes on to compare the city to Moloch:

Moloch whose eyes are a thousand blind windows! Moloch whose skyscrap-

ers stand in the long streets like endless Jehovahs! Moloch whose

factories dream and croak in the fog! Moloch whose smokestacks and

antennae crown the cities!

Biblically, the figure of Moloch is connected to the practice of child sacrifice, so then again to a youth that is being sacrificed to the city and capitalism-Caitlin Cater analyzes it as Ginsberg's fear of "the increasingly pervasive mass culture and [...] its deleterious impact on mankind" (Cater 2008, p. 15). And if we keep in mind Gilles Ivain's remark from his Formulaire pour un urbanisme nouveau that "Architecture is the simplest means of articulating time and space, to modulate reality, to make dream" (Ivain 1953), Ginsberg's poetry underlines thus that capitalism took over urbanism to make it a real nightmare. The whole poem recalls a quotation Marx Debord uses about the theory of the "dérive" in the second issue of Internationale Situationniste: "Men can see nothing around them that is not their own image" (Debord 1958b). Hopefully, and this might be the most important point in Ginsberg's work, the creative act can be, if not lifesaving, at least an impetus towards reawakening an awareness of our surroundings. This is precisely the mechanism at work in Ginsberg's "Sunflower Sutra", in which the ruins of an old locomotive (which could be interpreted as an industrial vision of America) form a big sunflower. Here, the poetic sensibility of the observers (Ginsberg and Kerouac) helps them to overcome the disenchantment of nature, while the poet advocates, on the contrary, for a re-enchantment of landscapes.

\section{Composing on/from the Tongue: Recording Geography}

But the psychogeographical aspect of Allen Ginsberg's poetry is also important in terms of methodology—as David Wills writes, "travel" gave Allen Ginsberg "opportunity to make significant poetic breakthroughs" (Wills 2019, p. 17). The most striking examples and tangible evidence of the impact of traveling on Ginsberg's methods of composition could be dated between December 1965 and March 1966. During that interval indeed, Allen Ginsberg read in many cities and was almost always on the road, in a car, or in a bus through Wichita, Kansas City, Bloomington, and more (sometimes in the company of Gary Snyder). Earlier that year, Bob Dylan gave Allen Ginsberg six hundred dollars so he could buy a brand-new tape-recorder. During that period, Allen Ginsberg recorded himself on his tape-recorder, improvising and creating spontaneous pieces, a vast majority of which is included in his book The Fall of America: Poems of These States. Allen Ginsberg's moving environment made it easier for him to record his thoughts rather than writing them. He himself called these poems a "kind of 
collage of the simultaneous data of the actual sensory situation" (Ginsberg 1980, p. 26). The poems published in The Fall of America are then born from movements, the poet being the active reader of his environment. These poems are therefore approaching and revealing the psychogeographical variations at work in Ginsberg's creative process in a very different way. This difference is a direct consequence of the time spent in a place and of the potential duration of geographical observations. In other words, the frontier between geography and the psyche is ever-changing, inducing thus, a new poetic structure, both in form and content. Allen Ginsberg's tape-recorder constitutes a precious archive tool, as the resulting tapes show that it was not only a way to record disconnected thoughts but a way to record lively lines and to include materials from his immediate environment.

Among the most relevant examples is a passage from his poem entitled "Bayonne Entering NYC":

More Chimney fires than all Kansas in a mile,

Sulphur chemical Humble gigantic viaducts

networked by road side

What smell burning rubber, oil

"freshens your mouth"

Railroad rust, deep marsh garbage-fume

Nostril horns-

city Announcer jabbering at City Motel (Ginsberg n.d.)

The word "horns" above is intentionally in bold character because it is in fact a fragment of the real, added in real-time into the poem. In the recording, Allen Ginsberg recorded those lines quite normally, when all of sudden, just after saying "nostril", one can hear horns in the background and Allen Ginsberg adding spontaneously the word "horns" in his recording, making those horns instantaneously and definitively part of the poem. In this example, the outside world of the city and the inside world of the poet are united, and the psychogeographical aspect of the poem is even more concrete. This incorporation of already existing elements into his poetry, a kind of collage of the real in a way, underlines at the same time the porosity of the frontier between the outside and the inside, but also the referentiality of the poem, as Ginsberg decided to keep those fragments of raw reality in his poems. To that extent, Ginsberg's poems of that period are made from and born in the landscapes through which he traveled.

Wichita Vortex Sutra, perhaps the best-known poem from that period, was also first tape-recorded-Allen Ginsberg told Michael Aldrich that this poem was "the transcription of only one day" (Ginsberg 1980, p. 26). Again, the poem is composed with elements taken from the flux of reality and those concrete elements were usually the impulse of Allen Ginsberg's recorded thoughts, both being mixed in the vortex of the poem. There is an interesting example of this creative vortex at the beginning of the poem:

Thy sins are forgiven, Wichita!

Thy lonesomeness annulled, O Kansas dear!

as the western Twang prophesied

thru banjo, when lone cowboy walked the railroad track

past an empty station toward the sun

sinking giant-bulbed orange down the box canyon-

Music strung over his back

and empty handed singing on this planet earth

I'm a lonely Dog, O Mother! (Ginsberg n.d.) 
Here again, the lines in bold characters are revealing, when compared to what could be considered Allen Ginsberg's first draft. One can hear how Ginsberg worked on this passage: he heard on the radio some country music, and he improvised over it, including the very song in his poem. The creative process, its imagery, and its structure are here inherent to the temporal and geographical structures perceived.

In another passage, from the poem rightly entitled "Hiway Poesy: L.A.-AlbuquerqueTexas-Wichita", Allen Ginsberg literally quotes a real conversation:

Hitchhiking student

supported by National Defense Fund

with his black horn rimmed glasses,

thin blond hair,

"If your country calls you, would you go?"

"If my country drafted me...

then I would go."

(Ginsberg n.d.)

Once again, those lines are taken from the vivid flux of life, as one can hear in the recording. This way of composing in real time with and from the outside world hooks and involves the reader into the vortex Ginsberg creates, where one cannot distinguish what is imagination and what is reality. This kind of collage also adds new shades of meaning by exploring words in a new context and therefore, could be understood in the vein of Gilles Deleuze and Felix Guattari's notions of de-territorialization and re-territorialization, in the sense that a fragment of the real is de-contextualized and re-contextualized - what was a trivial experience now becomes a poetical statement and shifted in category. Another example can be found in the line "Ham steak please waitress, in the warm café" in "Wichita Vortex Sutra", as Ginsberg tape-recorded himself ordering food in real-time in a café. For Deleuze and Guattari, the book (here the poem) is not "an image of the world" (Deleuze and Guattari 1987, p. 11) but "it assures the deterritorialization of the world" and "the world affects a reterri-torialization of the book" (Deleuze and Guattari 1987, p. 11). To borrow the words of the two philosophers, Ginsberg's poems are an "assemblage, a "multiplicity" made of "lines of articulation" as well as "movements of deterritorialization and destratification" (Deleuze and Guattari 1987, p. 3). In other words, Ginsberg's lines are creative movements-a process of shifting territories-from a world that builds upon itself and with its own raw material. In fact, this also recalls some characteristics of Deleuze and Guattari's concept of a rhizome: "Any point of a rhizome can be connected to anything other, and must be" and "a rhizome ceaselessly establishes connections between semiotic chains [ ... ]. A semiotic chain is like a tuber agglomerating very diverse acts, not only linguistic but also perceptive, mimetic, gestural, and cognitive" (Deleuze and Guattari 1987, p. 7). Ginsberg's poems could be then considered as poetic rhizomes: the lines know more than one ramification and layer and connect between themselves and each reader's experience in more than one direction.

The poems from that specific period are psychogeographical experiences and the occurrences that structure these experiences for the reader are too numerous to be listed here. But one can come across 
news broadcasts ${ }^{7}$, radio signals ${ }^{8}$, Ginsberg reading from newspapers ${ }^{9}$, declarations of the President ${ }^{10}$, and even a Bob Dylan's song-completing thus the circle:

Angelic Dylan singing across the nation

"When all your children start to resent you

Won't you come see me, Queen Jane?"

His youthful voice making glad

the brown endless meadows

His tenderness penetrating aether,

soft prayers on the airwaves, (Ginsberg n.d.)

In the recording of this passage, even though it is of poor quality, one can distinctly hear Bob Dylan singing in his unique voice-and once again, Dylan's lyrics are re-contextualized in a country at war. To paraphrase Deleuze and Guattari once again, "there is no difference between what a [poem] talks about and how it is made" (Deleuze and Guattari 1987, p. 4).

In those psychogeographical poems, Allen Ginsberg also underlines the extraordinary surfeit of language overflowing our environment to the point of being overused, with usually a strong emphasis on the manipulative side of language in the Vietnam War era, like in these lines (Ginsberg 2006, p. 409):

The war is language

language abused for advertisement, language used

like magic for power on the planet

Mathieu Perrot describes in that sense Ginsberg's "green poetry" and "ecological poetic" as a way to "reawaken consciousness put to sleep by the verbal pollution which hypnotizes the masses." (Perrot 2018, p. 46). But besides language, the place itself bears violence (Ginsberg 2006, p. 418):

Here fifty years ago, by her [Carry Nation] violence

began a vortex of hatred that defoliated the Mekong Delta-

7 (Ginsberg 2006, p. 402).

In advance of the Cold Wave

Snow is spreading eastward to

the Great Lakes

8 (Ginsberg 2006, p. 407).

Quietness, quietness

over this countryside

except for unmistakable signals on the radio

followed by the honkytonk tinkle

of a city piano

9 (Ginsberg 2006, p. 416).

Continued from page one area

after the Marines killed 256 Vietcong captured 31

ten day operation Harvest Moon last December

10 (Ginsberg 2006, p. 408).

"We will negotiate anywhere anytime" said the giant President. 
Proud Wichita! vain Wichita

cast the first stone!-

The place seems here to be morally poisoned by its inhabitants and instead of rippling throughout the land, this hauntological violence ripples through time.

This vortex of information, this juxtaposition of different materials unveils what is otherwise hidden in the landscape. In that sense, the reservoir of images present in the outside world is transformed into a Whitmanic scream by the poet so it can be heard by everyone, with shared materials that are accessible not only through imagination but also through a physical experience of the world. As he writes in Wichita Vortex Sutra (Ginsberg 2006, p. 414):

I search for the language

that is also yours-

Almost all our language has been taxed by war.

Moreover, in the works Allen Ginsberg composed during that period, changes in typographical treatment are also a creative process, as the experience of traveling influences not only the content but also the form of his poems. Indeed, Allen Ginsberg himself admitted that "When transcribing, [he] pai[d] attention to the clicking on and off of the machine", and described this process as writing in a "notebook", arranging the lines "according to their organic time-spacing as per the mind's coming up with the phrases and the mouth pronouncing them" (Ginsberg 1980, pp. 28-29). Here are lines from Wichita Vortex Sutra-the "clicking on and off" of the tape-recorder are represented here with an asterisk, according to the recording (Ginsberg n.d.):

While the triangle-roofed Farmer's Grain Elevator

sat quietly by the side of the road

along the railroad track *

American Eagle beating its wings over Asia *

million dollar helicopters *

a billion dollars worth of Marines *

who loved Aunt Betty*

Drawn from the shores and farms * shaking

from the high schools to the landing barge *

blowing the air thru their cheeks with fear *

in Life on Television *

Put it this way on the radio *

Put it this way in television language *

Use the words

language, language:

"A bad guess" *

Most of the time, the line breaks coincide with the "clicking on and off" of the tape-recorder, making each line a unit of thought. The layout of the poem is thus, deeply influenced by Allen Ginsberg's physical actions on the tape-recorder, actions which are themselves influenced by auditive or visual experiences during his travel. His use of a tape-recorder is in that sense a tool with which he sculpted his poem on the page but also a way to archive the poetry available in the world.

As we have seen, the notions of places and landscapes have a complex and pluralistic influence on Allen Ginsberg's poetry, whether words are taken from an always evolving geographical environment or born from a collective spirit of place. What is at work in most of the passages studied is a dynamic exchange between what is retrievable through poetry and what is lost in time, what is composed in the poem and what is archived in the mind. 


\section{Conclusions}

The psychogeographical poems of Ginsberg are the embodiment of an inner struggle, of a crisis that is deployed in a sensible field: the difficult process of transcribing the world and the poet's evanescent reactions to it into poetry, into a new vocabulary or context. Ginsberg's poetry is complex, subtle, but visionary-he welcomes the reader in his mind and in the vortex of the world itself. Introspective analysis of his position in the world is almost always a defining aspect of his poetry. Ginsberg, who described himself as "a permanent traveler" (Wills 2019, p. 129)—one could add, "a contemporary Ulysses"-is most of the time a psychogeographer without knowing it, someone who "wants to know and to create" ((Caritoux and Villard 2017, p. 72) My translation). He is not simply providing a passive description of his experience: he invites the reader to explore with him the liminal space between what is outside and what is inside, in the form of a creative and poetic study. In a way, Ginsberg's poetry transcends the notion of "dérive" as introduced by Guy Debord, as it is not a mere observation of psychogeographical variations or a poetic report that Ginsberg offers. It is, on the contrary, a deconstruction of horizontal observations, and a lively reconstruction of sceneries into a vertical work that allows the reader to oversee the environment.

Of course, the overlapping of the psyche and geography indirectly points towards the ambiguity of psychogeography: the observed environment is as influential as the observer's mindset. Poetry might be a solution to the impasse Guy Debord describes: "The sectors of the city are, at a certain level, decipherable. But the personal meaning they have for us is incommunicable" (Debord 2005, p. 129). In that sense, the poet is the medium between two worlds, as he is able, in his practice, to cross what Wunenburger called "the invisible line of scission" ((Caritoux and Villard 2017, p. 226) My translation). The psychogeographical poems of Allen Ginsberg are composed in a pendulum movement: from geographical triggers to poetic observations, from geographical observations to poetic triggers.

The Situationist vision of psychogeography, in the sense that it is a practice that invites the gathering of first-hand experiences of surroundings, and also to the extent that it is a non-mediated knowledge based on direct observations, is linked to what Guy Debord writes in his seminal book The Society of the Spectacle: "While eliminating geographical distance, this society produces a new internal distance in the form of spectacular separation." (Debord 2005, p. 2). In adding "psyche", that is a subjective element, to "geography", the work of the Situationist reintroduced the importance of the self, of relationship, of freedom. Ginsberg's poetry creates a poetic space in which the schizophrenic representation of the subject as against the outside world is negotiated, confronted, and finally abjured in the creative process. Landscapes, as poetic experiences, work in a reciprocal movement in Ginsberg's work. They are the poet's own tinted images and inclinations projected on an environment that, in return, swallows the poet in a union. Therefore, this union between the poet and the landscape appears more like a visionary harmony of a specific moment rather than a spontaneous poetic epiphany. Reading Ginsberg's poetry could be thus seen as an interiorized form of psychogeography, and as an examination of one's response to the environment. As for the mechanism at work for the layout on the page, this study scratched the surface of new territory to explore: a "text-ritory" to discover through poetico-geographical observations and genetic studies.

Translations of articles extracted from the magazines Internationale Situationniste and Potlatch are from The Situationist International Online unless stated otherwise.

Funding: This research received no external funding.

Conflicts of Interest: The author declares no conflict of interest.

\section{References}

Benjamin, Walter. 2000. OEuvres III. Paris: Gallimard.

Caritoux, Nathalie, and Florent Villard, eds. 2017. Nouvelles Psychogéographies. San Giovanni: Mimésis.

Cater, Caitlin. 2008. In Search of America: Nature, Spirituality, and the Self in American Transcendentalism and Beat Generation Literature. The Oswald Review 10: 4. 
Conord, André-Frank, ed. 1954a. Potlatch. no. 1. Paris: Éditions Allia, June 25.

Conord, André-Frank, ed. 1954b. Potlatch. no. 2. Paris: Éditions Allia, June 29.

Conord, André-Frank, ed. 1954c. Potlatch. no. 5. Paris: Éditions Allia, July 20.

Conord, André-Frank, ed. 1954d. Potlatch. no. 7. Paris: Éditions Allia, August 3.

Dahou, Mohamed, ed. 1954a. Potlatch. no. 9-10-11. Paris: Éditions Allia, August 17-31.

Dahou, Mohamed, ed. 1954b. Potlatch. no. 14. Paris: Éditions Allia, November 30.

Guy Debord, director. 2005, Critique of Separation (Film Soundtrack). Berkeley: Bureau of Public Secrets. First Published 1961.

Debord, Guy. 1955. "Introduction to a Critique of Urban Geography". Les Lèvres Nues \#6. Available online: http://library.nothingness.org/articles/SI/en/display/2 (accessed on 28 August 2020).

Debord, Guy, ed. 1957. Potlatch. no. 29. Paris: Éditions Allia, November 5.

Debord, Guy-Ernest, ed. 1958a. Internationale Situationniste. no. 1. Paris: Editions Champ Libre, June.

Debord, Guy-Ernest, ed. 1958b. Internationale Situationniste. no. 2. Paris: Editions Champ Libre, December.

Debord, Guy-Ernest, ed. 1959. Internationale Situationniste. no. 3. Paris: Editions Champ Libre, December.

Debord, Guy. 2005. The Society of the Spectacle. London: Rebel Press.

Debord, Guy. 2008. A Sick Planet. Oxford: Seagull Books.

Deleuze, Gilles, and Félix Guattari. 1987. A Thousand Plateaus: Capitalism and Schizophrenia. Minneapolis: University of Minnesota Press.

Geneson, Paul, and Allen Ginsberg. 1975. A Conversation with Allen Ginsberg. Chicago Review 27: $27-35$. [CrossRef]

Ginsberg, Allen. 1980. Composed on the Tongue Essays, Lectures and Interviews. Bolinas: Grey Fox Press.

Ginsberg, Allen. 2006. Collected Poems: 1947-1997. New York: Harper Collins.

Ginsberg, Allen. n.d.a. “A Vow \& Iron Horse. Reel/DAT 23 + 24." Allen Ginsberg Papers 1937-2017. Department of Special Collections and University Archives, Stanford Libraries. Available online: https://searchworks. stanford.edu/view/kt081tb6136 (accessed on 28 August 2020).

Ginsberg, Allen. n.d.b. "Auto Poesy Recorded at Various Locations." Allen Ginsberg Papers 1937-2017. Department of Special Collections and University Archives, Stanford Libraries. Available online: https: //searchworks.stanford.edu/view/qr659pt3195 (accessed on 28 August 2020).

Ivain, Gilles. 1953. Formulary for a New Urbanism. Bureau of Public Secrets. Available online: http: //www.bopsecrets.org/SI/Chtcheglov.htm (accessed on 28 August 2020).

Manes, Christopher. 1996. "Nature and Silence". In The Ecocriticism Reader: Landmarks in Literary Ecology. Athens: The University of Georgia Press, pp. 15-30.

Marcus, Greil. 2011. Lipstick Traces: A Secret History of the Twentieth Century. London: Faber \& Faber.

Meltzer, David, ed. 2001. San Francisco Beat: Talking with the Poets. San Francisco: City Lights Books.

Perrot, Mathieu. 2018. La sagesse des relations terrestres. Essais 13: 33-50. [CrossRef]

Stephenson, Gregory. 2009. The Daybreak Boys: Essays on the Literature of the Beat Generation. Carbondale: Southern Illinois University Press.

Westphal, Bertrand. 2011. Geocriticism: Real and Fictional Spaces. London: Palgrave Macmillan.

Wills, David. 2019. World Citizen: Allen Ginsberg as a Traveller. Temple: Beatdom Books.

(C) 2020 by the author. Licensee MDPI, Basel, Switzerland. This article is an open access article distributed under the terms and conditions of the Creative Commons Attribution (CC BY) license (http://creativecommons.org/licenses/by/4.0/). 